\title{
The Economic Value of Book Loans - The Case of the Municipal Library of Prague
}

\begin{abstract}
In recent years, the value of public library services has tended to be evaluated using the contingent valuation method. This is able to reveal readers' hidden preferences. However, it appears that the total value of a public library as expressed by one number leads to a methodological bias related to the difficulty of assessing the value of one standard book loan. Moreover, this approach does not reflect the needs of the public libraries' management. Therefore, this study focuses on a detailed investigation of the most important public library service, book loans. For this purpose, we have employed statistical models to identify the significant determinants of willingness to pay (WTP) for book loans and WTP for purchasing books, respectively. The results suggest that loan services have the greatest perceived value for students, people who are economically active. Management who are interested in increasing the success of their institution across society must also know the perceived value of individual books so that they can adjust their library's acquisition policy. It was found that novels had the highest perceived value, followed by educational literature in the fields of economics and education as well as information science. This entirely new analytical method of measuring WTP for public services raises many new implications that could change the strategies of individual libraries - as well as the public policy strategies of donors and library ownership.
\end{abstract}

Keywords: public libraries, economic value, book loans, case study

\section{Introduction}

Recently, public service providers in individual European countries have been facing unprecedentedly strong pressure from their donors to optimize (frequently to lower) their budgets and the amounts allocated for their operation from the national budget. Many studies, originating as early as the end of the 1990's (e.g., Vitaliano, 1998; Worthington, 1999; Hammond, 2002; Hemmeter, 2006), have recorded this trend. Managers and leading officials of the public service providers are faced with an even more complicated situation because, for them, this results in rising costs and stagnant or decreasing revenues, which are influenced by the individual country's economic situation. However, certain public service providers are faced with an even more complicated situation, because their importance is judged and compared with services such as health care or social services, public transportation, or the current security situation. In such comparisons, providers of cultural or informational services are always in last place (Simpson, 2009).

If library management does not begin to address its effectiveness using modern methods and approaches, it will inevitably result in savings from reductions in the spectrum of services, quality, and availability (Vitaliano, 1998; Kuipers et al., 2014) or the closure of certain libraries. To adequately manage their own effectiveness, it is necessary to have sufficient and precise information concerning their performance (Worthington, 1999; Andrew et al., 2012), user requirements (both interested parties - readers - as well as non-interested parties - ordinary citizens, non-readers), and the content of public commissions from donating organizations in the 
public sector. All the interested parties evaluate the library's performance and judge its effectiveness from their points of view.

There are many studies that deal with measuring the effectiveness or performance of public libraries. Each of these uses a specific analytical approach - for example, proponents of microeconomic theory evaluate allocative efficiency in public libraries as a major concern in public finance (Frantz, 1992), supporters of social theories evaluate how libraries fulfill their mission in the area of education, dissemination of information, and continuing education (they evaluate whether public goods are over- or under-provided; Falkinger et al., 2000; López, 2005); other well-known approaches to evaluation include government productive efficiency (De Borger, 2000; Dunn, 2004) and many others. These all view the evaluation of public library outputs within the context of the "age of accountability" and are based on measuring benefits and costs.

Only rarely do any of these methods concern themselves with evaluating the effectiveness of individual services (Stolarick, Silk, 2013); however, all the studies do analyze library services as a whole. This is mostly because of the demands of such analysis on primary data. On the other hand, determining the level of effectiveness (or return on investment - ROI) for individual book loans can make the information necessary for correctly directing services, i.e., for management's decision making, distinctly more precise. Previous attempts at determining the value of individual book loans encountered the problem of determining the value of a standard book loan (Morris et al., 2001). Therefore, it is more customary to question users as to the benefit of the last book loan. However, the value of specific book loans is biased by several determinants not considered in previous research such as the actual price, genre, or age of the book. This paper aims to bridge this gap in the literature and to analyze individual groups of value determinants for loans using the example of an extensive empirical survey at the Municipal Library of Prague. We demonstrate that the value of book loans is strongly connected to the willingness of users to pay for the purchase of the corresponding book. On the other hand, there are differences between the determinants of these related values.

The rest of the paper is structured as follows. Section 2 briefly reviews the literature on evaluating public library services. Section 3 describes our research methodology, including the empirical survey and data analysis. Section 4 presents the results of our research. The final section concludes the paper and outlines several political implications.

\section{Methods of Measuring Public Library Outputs}

All the approaches listed, however, must use some type of method to measure and evaluate the individual outputs of the public service provider, i.e., the public library. Van House (1989) adds that performance measures refer collectively to several kinds of measures that reflect the performance of the organization (inputs or resources used; processes or measures reflecting internal operations; productivity or the ratio of outputs to inputs; outputs, that is, the extensiveness and effectiveness of services delivered; and outcomes, the most difficult to measure, the effects of the services provided on clients and society). Lynch (1993) points 
out that, in many service sectors (including public libraries), output depends on interaction with the user and that it is necessary to take this into account during its quantification and assessment.

The primary activity of a public library is to loan books, magazines, and other media. One study (Stejskal et al. 2013) for the Municipal Library of Prague confirms that loans (checked out books and other library items and in-library loans) account for $85 \%$ of all public library costs, making them the library service with highest impact on library effectiveness. Also research performed for the same study revealed that more than $86 \%$ of library users loan a library item at least once a year (86.71 \% non-assisted and $52.31 \%$ assisted out-of-library loans; cumulative amount is not available). That research also revealed that more than $78 \%$ of users considers library loan being "very important", giving them highest score at 5 points scales, which identified loans as being the most important library service.

Among the other services that the library offers are digital services, providing information and research, cultural and educational services, and residency services (Hajek, Stejskal, 2014). Certain authors emphasize primarily increasing the significance of digital services and recommend that libraries focus on providing these. Ferguson (1997) encourages exchanging paper books for e-books and primarily providing the services of an electronic library; Gatenby (2008) proposes providing digital services via a "networked library service layer." However this requires standardized services in order to be implemented. Jantz (2001) supports this trend and suggests using new library service models for increasing the effectiveness of the services provided. Recent studies focus on libraries' WTP for e-books (Besen and Kirby, 2014). However, all authors emphasize the need to clearly define individual services, measure the helpfulness of the provided services, and analyze their effectiveness so that library management knows which of the services bring the greatest well-being across society.

Walter (2003) states that, as early as the 1980's, local governments in certain countries were interested in how to measure the output of public libraries - because of the necessity of distributing public funds effectively. Therefore, the document Output Measures for Public Libraries (Van House et al., 1987) was created as early as 1987; it proposes a way to measure the value of public services provided by libraries. However, it did not provide methods affecting the libraries' outcomes, but only their outputs. However, there is a significant difference between them. Outputs are the quantifiable service products, such as numbers of books circulated or questions answered, the number of children attending storytimes, or the number of adults participating in volunteer efforts. Outcomes are the quantifiable results of those services. They attempt to measure the differences made to an individual as a result of checking out a book, or attending a storytime, or volunteering at the library. Despite this, methods based on input/output emerged in the following years (primarily derived from library accounting). However, there was also an attempt for a different perspective, i.e., expressing the benefits that the library brings to its users. For libraries, the first attempts date to the year 2000 (the St. Louis CBA project; Holt, Elliott, Watts, \& Holt, 2000). Weil (2000); Rudd (2000); and Holt, G. E., \& Elliott, D. (2003) - plus other authors in the following years - supported the belief that the library community 
can build a strong case for its continued economic legitimacy by measuring the benefits that libraries provide their constituents.

The methods based on measuring benefit and costs are still in use today for measuring the effectiveness of individual library services (either in the form of CBA or return-on-investment). For evaluating user benefits, various tools are used: the measurement of direct and indirect benefits, consumer surplus, or contingent valuation methods. According to Holt, G. E., \& Elliott, D. (2003), the last of these methods requires a respondent to value a scenario depicting a counterfactual state of the world relative to the existing state of the world. Two alternative approaches are described in the economics literature. In the willingness-to-pay approach (WTP), interviewers ask respondents how much they would be willing to pay to have something that they currently do not have. In the willingness-to-accept approach (WTA), interviewers ask respondents how much they would accept to give up something that they already have. The use of the WTP approach is confirmed by a number of studies where they were used (e.g., Noonan, 2003; Aabø, 2005a; Hider, 2008; Lee \& Chung, 2012; Kingma et al., 2015).

The determinants of public library value have been investigated only recently. Ko et al. (2012) showed that a higher baseline WTP in the hypothetical market leads to a higher average WTP value for public library services. This study also argues that WTP was higher for men and it was higher for people with higher levels of education. Neither general nor erroneous altruism showed a significant correlation with WTP in Lee et al. (2012). Hajek and Stejskal (2014) used various payment mechanisms with the contingent valuation method. The WTP where people decide on the allocation of a certain amount of their taxes (tax decrease or increase) represents a compromise between the out-of-pocket WTP and the in-pocket WTA approaches. The main determinants of public library value included available household income, the services' frequency of use, and alternative costs. Moreover, the importance of book loan services was the value's major determinant. Ko et al. (2015) examined additional determinants related specifically to university libraries. They found that the only determinant that seemed to affect the WTP for library services was the users' status, indicating that faculty members showed a significantly higher WTP than students.

\section{Data}

The research was carried out in the form of an empirical survey from June to September of 2015. The survey focused on determining the value of book loans for the Municipal Library of Prague (MLP), which is the largest public library in the Czech Republic (4 billion books checked out yearly). The basic tool was an online CAWI questionnaire. Its wording was examined during pilot testing from March to May of 2013. In this way, we made sure that the respondents would understand the questions asked.

The basic sample of respondents was made up of readers at the MLP. Every reader had to meet the following criteria: being age 15+ and having an e-mail address. A simple random selection was made from the database of readers meeting the determined criteria that was supplied. Each of the respondents was asked to fill out a 
questionnaire via an individualized e-mail with a unique link to this questionnaire. The questionnaire was related to one specific loan and the e-mail was sent exactly after one month after the initial loan (to have enough time to read it). The respondents received a confirmation letter after filling out the questionnaire. The average time it took to fill out a questionnaire was 6.8 minutes.

The total rate of return was $34.6 \%$; the questionnaire was completed by 8,570 respondents out of the 21,854 approached and out of the 180,669 readers who used their library card during the 2015 (the overall population of the City of Prague was $1,267,000)$. The basic data set obtained was cleaned using standard verification procedures as used by sociological methodologies.

The average age of the respondents was 47.1 years while the average age of registered library users (age 15+) according to the library records was 41 . The average number of household members was 2.6. In the group of readers, the number of women was significantly greater (77.5\%), see Table 1 . However this high percentage of female respondents generally matches the library records, according which $70.4 \%$ of registered readers (age 15+) were women. About half of the respondents had a university education. More than half of them were economically active. The household income was most frequently between CZK 15,000 - 29,999 (39.1 \%) $(1 \mathrm{EUR}=27 \mathrm{CZK}, 1 \mathrm{USD}=24 \mathrm{CZK})$.

Table 1: Socio-economic and demographic characteristics of the readers

\begin{tabular}{|c|c|}
\hline Variable & Frequency \\
\hline \multirow[t]{2}{*}{ Gender } & Male: 2158 (22.5\%) \\
\hline & Female: 7452 (77.5\%) \\
\hline \multirow[t]{4}{*}{ Education } & Basic / apprenticeship: 295 (8.6\%) \\
\hline & Secondary: 1158 (33.8\%) \\
\hline & Post-secondary: 280 (8.2\%) \\
\hline & University: 1692 (49.4\%) \\
\hline \multirow[t]{5}{*}{ Socio-economic status } & Student: 465 (13.5\%) \\
\hline & Housewife, maternity leave/parental leave: 225 (6.6\%) \\
\hline & Pensioner: 716 (20.9\%) \\
\hline & Unemployed: 95 (2.8\%) \\
\hline & Economically active: 1931 (56.3\%) \\
\hline \multirow[t]{5}{*}{ Household income (CZK) } & 1: Less than 15,000: 450 (14.9\%) \\
\hline & 2: 15,000-29,999: 1183 (39.1\%) \\
\hline & 3: 30,000-44,999: 754 (25.0\%) \\
\hline & 4: 45,000-59,999: 414 (13.7\%) \\
\hline & 5: 60,000-74,999: 116 (3.8\%) \\
\hline
\end{tabular}


6: 75,000 and more: 105 (3.5\%)

\begin{tabular}{lc}
\hline The number of book loans per year & 11.2 on average \\
\hline Age & 47.1 on average \\
\hline The number of household members & 2.6 on average \\
\hline
\end{tabular}

The descriptive statistics of the questions related to book loans are presented in Table 2 .

Table 2: Descriptive statistics of book loans

\begin{tabular}{|c|c|}
\hline Variable & Frequency \\
\hline \multirow[t]{7}{*}{ Purpose of the loan } & $\begin{array}{l}\text { Building-up of hobbies, voluntary activities } \\
\text { etc.: } 664(12.7 \%)\end{array}$ \\
\hline & Study (teacher): 91 (1.7\%) \\
\hline & Relaxation: 3523 (67.5\%) \\
\hline & Study (student): 340 (6.5\%) \\
\hline & Work: 95 (1.8\%) \\
\hline & Personal problems: 177 (3.4\%) \\
\hline & Other: $329(6.3 \%)$ \\
\hline \multirow[t]{4}{*}{ Circumstances of the loan } & Targeted title: 3235 (33.8\%) \\
\hline & Random choice: 3477 (36.4\%) \\
\hline & Targeted author: 2465 (25.8\%) \\
\hline & Other: 382 (4.0\%) \\
\hline \multirow[t]{5}{*}{ Contribution of the book loan } & 1: absolutely unimportant: $723(8.2 \%)$ \\
\hline & 2: rather unimportant: 1178 (13.4\%) \\
\hline & 3: average importance: 3371 (38.4\%) \\
\hline & 4: rather important: 2466 (28.1\%) \\
\hline & 5: absolutely important: 1030 (11.7\%) \\
\hline Alternative costs of acquiring the book & $70.6 \mathrm{CZK}$ \\
\hline \multirow{4}{*}{$\begin{array}{l}\text { Complications caused by unavailability of } \\
\text { the book }\end{array}$} & 1: absolutely yes: 84 (4.0\%) \\
\hline & 2: rather yes: 288 (13.7\%) \\
\hline & 3: rather no: 770 (36.7\%) \\
\hline & 4: absolutely no: 954 (45.5\%) \\
\hline Year of publication & 2009 average \\
\hline Price of book & 283.3 CZK on average \\
\hline
\end{tabular}




\begin{tabular}{ll}
\hline Genre & Professional: $2695(28.1 \%)$ \\
& Fiction: $6718(69.9 \%)$ \\
& Periodical: $141(1.5 \%)$ \\
& Poetry: $48(0.5 \%)$ \\
\hline WTP_buy & 151.1 CZK on average \\
\hline WTP_loan & 61.1 CZK on average \\
\hline
\end{tabular}

Relaxation was the most common reason for the book loan at $67.5 \%$. The circumstances surrounding the loans are almost evenly distributed among specific title, random title, and specific author. The readers were also asked to assess the benefit gained from book loans. Mostly, the loans were evaluated as being of average importance or rather important. As an alternative, the readers preferred a similar book or borrowing a book from friends. The readers were asked the following question: Which option would you prefer and what would be the related alternative costs of acquiring the book: (a) to buy the same book as an e-book, (b) to buy the book in a bookshop, (c) to buy the book at an internet auction (eBay, etc.), (d) to buy the book in an antiquarian bookshop, (e) to loan the book from friends, (f) try to find a free copy of the book in the internet, and $(\mathrm{g})$ to loan the book in another library. The alternative would not be a complication for the readers. The average book age was roughly 6 years, and the books were worth 283.3 CZK on average. The price of book and the year of publication were obtained from the acquisition database of the library. More than half of the books were fiction.

The readers' WTP was assessed by two questions introducing two distinct hypothetical situations:

1) Imagine that this title is not available either in the MKP or in any other library; nobody from your surroundings possesses this book, and it is not available for sale. You found only one copy in an antiquarian bookshop. What is the maximum amount would you be willing to pay for this title?

2) Imagine that the owner of the antiquarian bookshop is not willing to sell his only copy, because he promised it to another interested person. However, he is willing to loan (lease) the book for a onemonth period. What is the maximum amount would you be willing to pay for the loan?

We labeled the first WTP as WTP_buy since it represents the price for buying the book and the second one as WTP_loan (the price for a one-month loan). WTP_buy is more than two-fold.

\section{Experiment Results}

Correlation coefficients were first employed to test the dependencies between the numerical variables and WTP_buy and WTP_loan, respectively (Table 3). 
Regarding the socioeconomic characteristics of the reader, older readers were willing to pay significantly less for both the purchase and the loan of the books. Surprisingly, the level of the reader's education had the opposite effect than what was expected. This can be explained by correlating the reader's education with other socioeconomic variables such as age and socioeconomic status. Furthermore, household income was not significantly correlated with either WTP_buy or WTP_loan. A greater number of household members significantly increased the readers' WTP. Finally, frequent readers assigned significantly lower values to both WTP_buy and WTP_loan.

The variables related to book loans correlated with the WTP values in accordance with expectations. Book price was more strongly correlated with WTP_buy. A similar situation was also true for publication year and alternative costs, respectively. The benefit from the book loan was also strongly correlated with both WTP_buy and WTP_loan.

\section{Table 3: Correlation coefficients}

\begin{tabular}{lll}
\hline & WTP_buy & WTP_loan \\
\hline reader's age & $-0.161^{* * *}$ & $-0.155^{* * *}$ \\
reader's education & $-0.042^{* *}$ & $-0.056^{* * *}$ \\
household income & 0.020 & -0.011 \\
household members & $0.063^{* * *}$ & $0.064^{* * *}$ \\
\hline book loans per period & $-0.068^{* * *}$ & $-0.038^{* *}$ \\
\hline book price & $0.100^{* * *}$ & $0.081^{* * *}$ \\
public. year & $-0.085^{* * *}$ & -0.004 \\
alter. costs & $0.280^{* * *}$ & $0.234^{* * *}$ \\
\hline contribution of the book loan & $0.267^{* * *}$ & $0.278^{* * *}$ \\
\hline
\end{tabular}

* significant at $0.1, * *$ significant at $0.05, * * *$ significant at 0.01

Next, we employed linear regression models to show the effects of the socioeconomic determinants on the WTP values. For all regression models, we did not observe any violation of the model assumptions, including multicollinearity (variance inflation factors $<2.5$ ), heteroscedasticity (the Levene's tests with $p>0.05$ ), normality of unstandardized residuals (the Shapiro-Wilk tests with $p>0.05$ ), and first order linear autocorrelation (the Durbin-Watson statistics between the critical values of $1.5<d<2.5$ ).

Table 4 shows that age and related socioeconomic status are the most important determinants of both WTP_buy and WTP_loan. It is interesting that men were willing to pay significantly more for purchasing books in comparison with women, whereas this effect was not important for loans. Education was shown to be an 
insignificant determinant in both models. However, the number of household members was important for WTP_loan as was income. Income, however, had the opposite effect.

In the second run of regression models, we examined the effects of the determinants related to book loans (Table 5 and Table 6). Alternative costs, contribution, price of book and complications were significant determinants in all three models. In the first model, we examined the effects of purpose and circumstances of the book loan. The effect of building-up of hobbies was significantly positive, whereas relaxation was a negative determinant of WTP (but not significantly). Similarly, targeted title was important for WTP_buy in particular, whereas the effect of random choice was negative in this case. In the second model, we examined the effect of general genres (professional, fiction and periodical), which showed insignificant effects. In the third model, the genres were categorized in detail. We provide evidence for different impacts of individual genres on WTP_buy and WTP_loan, respectively. Whereas professional genres were important for both WTP_buy and WTP_loan, the presented fiction genres were significantly positive determinants of WTP_loan only.

Table 4: Regression models for socio-economic variables - $t$-values ( $p$-values).

\begin{tabular}{|c|c|c|}
\hline Variable & WTP_buy & WTP_loan \\
\hline Intercept & $1.188(0.235)$ & $8.260(0.000)^{* * *}$ \\
\hline Age & $-4.081(0.000)^{* * *}$ & $-3.646(0.000)^{* * *}$ \\
\hline Sex (male -0 , female -1$)$ & $-3.243(0.001)^{* * *}$ & $-0.296(0.767)$ \\
\hline Education & $-0.882(0.378)$ & $-1.223(0.262)$ \\
\hline Income & $-0.538(0.590)$ & $-2.263(0.024)^{* *}$ \\
\hline Household members & $1.311(0.180)$ & $1.982(0.048)^{* *}$ \\
\hline Book loans per period & $-2.398(0.017)^{* *}$ & $-1.223(0.220)$ \\
\hline \multicolumn{3}{|l|}{ Socio-economic status } \\
\hline \multicolumn{2}{|c|}{ Student $2.195(0.028)^{* *}$} & $3.289(0.001)^{* * *}$ \\
\hline \multicolumn{2}{|c|}{ Housewife, maternity-2.002 $(0.045)^{* *}$} & $-2.499(0.013)^{* *}$ \\
\hline \multicolumn{2}{|c|}{ Pensioner-0.091 (0.927) } & $-0.318(0.751)$ \\
\hline \multicolumn{2}{|c|}{ Economically active $-0.813(0.416)$} & $-1.738(0.082)^{*}$ \\
\hline$R$ & 0.193 & 0.200 \\
\hline $\mathrm{R} 2$ & 0.037 & 0.040 \\
\hline R2 - adj. & 0.034 & 0.037 \\
\hline $\bar{N}$ & 2729 & 2708 \\
\hline
\end{tabular}

* significant at $0.1, * *$ significant at $0.05, * * *$ significant at 0.01 
Table 5: Regression models for variables related to book loans - $t$-values ( $p$-values).

\begin{tabular}{|c|c|c|c|c|}
\hline Variable & WTP_buy & WTP_loan & WTP_buy & WTP_loan \\
\hline Intercept & $0.080(0.936)$ & $-2.950(0.003)^{* * *}$ & $2.143(0.032)^{* *}$ & $3.258(0.001)^{* * *}$ \\
\hline Alternative costs & $8.410(0.000)^{* * *}$ & $8.652(0.000)^{* * *}$ & $7.260(0.000)^{* * *}$ & $8.497(0.000)^{* * *}$ \\
\hline Contribution & $2.681(0.007)^{* * *}$ & $3.073(0.002)^{* * *}$ & $3.273(0.001)^{* * *}$ & $3.203(0.001)^{* * *}$ \\
\hline Price of book & $2.099(0.036)^{* *}$ & $1.993(0.046)^{* *}$ & $3.815(0.000)^{* *}$ & $2.904(0.004)^{* * *}$ \\
\hline Year of publication & $-0.323(0.747)$ & $2.614(0.009)^{* * *}$ & $-2.816(0.029)^{* *}$ & $-3.303(0.001)^{* * *}$ \\
\hline Complications & $4.941(0.000)^{* * *}$ & $8.115(0.000)^{* * *}$ & $4.941(0.000)^{* * *}$ & $9.441(0.000)^{* * *}$ \\
\hline \multicolumn{5}{|l|}{ Purpose } \\
\hline $\begin{array}{r}\text { Building-up of } \\
\text { hobbies }\end{array}$ & $2.622(0.009)^{* * *}$ & $2.094(0.036)^{* *}$ & & \\
\hline Relaxation & $-0.647(0.518)$ & $-1.305(0.192)$ & & \\
\hline Study (student) & 1.163 (0.173) & $1.142(0.155)$ & & \\
\hline \multicolumn{5}{|l|}{ Circumstances } \\
\hline Targeted title & $1.779(0.075)^{*}$ & $1.162(0.245)$ & & \\
\hline Random choice & $-1.899(0.058)^{*}$ & $-0.458(0.647)$ & & \\
\hline \multicolumn{5}{|l|}{ Genre } \\
\hline Professional & & & $0.287(0.774)$ & $-0.296(0.768)$ \\
\hline Fiction & & & $0.584(0.559)$ & $0.174(0.862)$ \\
\hline Periodical & & & $0.200(0.841)$ & $0.328(0.743)$ \\
\hline$R$ & 0.335 & 0.394 & 0.313 & 0.394 \\
\hline $\mathrm{R} 2$ & 0.113 & 0.155 & 0.098 & 0.155 \\
\hline R2 - adj. & 0.104 & 0.148 & 0.093 & 0.150 \\
\hline$N$ & 1700 & 1625 & 1648 & 1631 \\
\hline
\end{tabular}

* significant at $0.1,{ }^{* *}$ significant at $0.05,{ }^{* * *}$ significant at 0.01

Table 6: Regression models for variables related to book genres - $t$-values ( $p$-values).

\begin{tabular}{lll}
\hline Variable & WTP_buy & WTP_loan \\
\hline Intercept & $1.857(0.064)^{*}$ & $2.764(0.006)^{* * *}$ \\
Alternative costs & $6.447(0.000)^{* * *}$ & $8.080(0.000)^{* * *}$ \\
Contribution & $2.392(0.017)^{* *}$ & $2.368(0.018)^{* *}$
\end{tabular}




\begin{tabular}{lll}
\hline Price of book & $4.169(0.000)^{* * *}$ & $2.970(0.003)^{* * *}$ \\
Year of publication & $-1.881(0.060)$ & $-2.805(0.005)^{* * *}$ \\
Complications & $4.961(0.000)^{* * *}$ & $8.135(0.000)^{* * *}$
\end{tabular}

Purpose

Building-up of hobbies $3.327(0.001)^{* * *} \quad 3.479(0.001)^{* * *}$

$$
\begin{array}{rr}
\text { Relaxation } 0.234(0.815) & 0.614(0.539) \\
\text { Study (student) }-1.099(0.272) & 0.860(0.390)
\end{array}
$$

Circumstances

$$
\begin{array}{cc}
\text { Targeted title } 0.296(0.768) & 0.516(0.606) \\
\text { Random choice }-1.787(0.074)^{*} & -0.440(0.660)
\end{array}
$$

\begin{tabular}{|c|c|c|}
\hline \multicolumn{3}{|c|}{3 (theatre, film) $1.657(0.098)^{*}$} \\
\hline \multicolumn{2}{|c|}{7 (geography) $-2.544(0.011)^{* *}$} & $-1.651(0.099)^{*}$ \\
\hline \multicolumn{2}{|c|}{15 (politics) $-1.821(0.069)^{* *}$} & $-2.487(0.013)^{* *}$ \\
\hline \multicolumn{2}{|c|}{4 (economics) $2.212(0.027)^{* *}$} & $2.327(0.020)^{* *}$ \\
\hline \multicolumn{2}{|l|}{22 (education) } & $2.973(0.003)^{* * *}$ \\
\hline \multicolumn{2}{|l|}{12 (computer and } & $2.245(0.025)^{* *}$ \\
\hline \multicolumn{3}{|l|}{ information sciences) } \\
\hline \multicolumn{2}{|l|}{24 (agriculture) } & $-1.695(0.090)^{*}$ \\
\hline \multicolumn{2}{|l|}{ Fiction - memoir } & $1.650(0.099)^{*}$ \\
\hline \multicolumn{2}{|l|}{ Fiction - war novel } & $2.811(0.005)^{* * *}$ \\
\hline \multicolumn{2}{|l|}{ Fiction - detective } & $1.809(0.071)^{*}$ \\
\hline \multicolumn{2}{|l|}{ Fiction - humorous } & $1.766(0.078)^{*}$ \\
\hline $\mathrm{R}$ & 0.347 & 0.439 \\
\hline R2 & 0.120 & 0.193 \\
\hline R2 - adj. & 0.095 & 0.165 \\
\hline$N$ & 1610 & 1582 \\
\hline
\end{tabular}

Genre

\footnotetext{
* significant at $0.1,{ }^{* *}$ significant at $0.05,{ }^{* * *}$ significant at 0.01
}

\section{Discussion and Concluding Remarks}

In contrast to previous studies focused on a standard book loan, we questioned users to assign WTP of the specific book loan. To avoid bias related to determinants such as the actual price or genre, we examined the 
determinants of the loan value using the data collected through the empirical survey at the Municipal Library of Prague, the Czech Republic.

From our research, it can be seen that: (1) only several socioeconomic characteristics proved to be important for WTP, namely socioeconomic status and the related age of the readers; (2) the book loan has a higher value when it is used for professional purposes and when it is targeted, respectively; and (3) alternative costs significantly affect the WTP for books.

Specifically, the WTP value shows significant positive correlation for gender (male), education, income, household members, and insignificant negative correlation for age. Age and economic status are the most significant factors for both book purchase and loan. These results are confirmed by the results of a study by Lee and Chung (2012) where age was more correlated with WTP than economic activity. On the other hand, age did not correlate significantly with WTP in the study by Lee et al. (2010). The respondent's gender was not important for WTP in Lee et al. (2010) and Lee and Chung (2012). In the study by Lee et al. (2010), academic background correlated significantly with WTP; on the other hand, studies by Aab $\varnothing$ (2005b) and Lee and Chung (2012) found educational level to be insignificant. A higher income and more frequent visits and use of library services were connected to placing a higher value on the library in all of the models (Hájek and Stejskal, 2015). Visit frequency did not correlate with WTP in Lee and Chung (2012). Income amount correlated positively with WTP in Lee et al. (2010). The discrepancies in the individual studies' results can be the result of the historical, cultural, and social foundations of the individual societies that shape humanity's social values. To a large degree, this determines the perception of libraries as a societal institution and the significance of their role as providers not only of information and education but also of cultural and social values.

Complications connected to the library's unavailability were important in the WTP model (Hájek and Stejskal, 2015). Our results confirm the same finding. Likewise, we confirmed that alternative costs were important factors for the library's value in all of the models proposed (this is consistent with Hájek and Stejskal, 2015). Aabø (2005b) used distance from the library, which was also an important factor of WTP.

The following political implications may be derived from the results presented here. Since book loans currently represent not only the most expensive service (measured by total cost) but also both the most important and the most frequently used public library service, the managers of public libraries should pay particular attention to this service. Traditionally the total number of loans per year is one of the main key performance indexes. But the research shows that there are important differences between different loans. Therefore the main effort should be spent not on maximizing the number of loans but to the cumulative value of them (measured using WTP). In order to increase the value of book loans, public libraries should focus on:

(1) specific target groups - in our test environment we can especially emphasize students;

(2) specific genres - in our test environment especially novels (mainly war novels), professional literature, economics and education, computer and information sciences; and 
(3) providing information on the availability of specific titles and references to titles from the same author, respectively.

Management can use knowledge of the WTP values that readers ascribe to specific literary genres to increase the overall benefit provided (their library's ROI). However, it is important to say that focusing on a specific genre does not necessary means to buy everything published in multiple copies. Increasing of effectiveness cannot be achieved only by increasing the benefit value, costs must be considered too. It is also necessary to call attention to the fact that perceived WTP changes over time and is subject to the current trends of fashion or society. Moreover, it quite certainly does not correspond with a socially necessary focus on reading and on educating the population in order to instill them with desirable social values, increase their level of education, and reinforce other positive characteristics.

The main limitation of our study lies in the specifics of the public library used in this paper. To overcome this limitation, further studies should be conducted to make the models more general. In future research, we would also like to see analyses focused on international comparisons. Further work should also be conducted on a more detailed evaluation of the subjective benefits the book loan provides the reader.

\section{Acknowledgements}

We gratefully acknowledge the help provided by constructive comments of the anonymous referees.

\section{References}

Aabø, S. (2005a). Are public libraries worth their price? A contingent valuation study of Norwegian public libraries. New Library World, 106(11/12), 487-495.

Aabø, S. (2005b). Valuing the Benefits of Public Libraries. Information Economics and Policy, 17(2), 175-198.

Aabø, S. (2009). Libraries and Return on Investment (ROI): A Meta-Analysis. New Library World, 110(7/8), 311324.

Andrews, R., Boyne, G. A., Meier, K. J., O'Toole, L. J., \& Walker, R. M. (2012). Vertical strategic alignment and public service performance. Public Administration, 90(1), 77-98.

Bawden, D., Calvert, A., Robinson, L. \& al. (2009). Understanding our Value; Assessing the Nature of the Impact of Library Services. Library and Information Research, 33(105), 62-89.

Besen, S. M., \& Kirby, S. N. (2014). Library demand for e-books and e-book pricing: An economic analysis. Journal of Scholarly Publishing, 45(2), 128-141.

Chung, H. K. (2008). The Contingent Valuation Method in Public Libraries. Journal of Librarianship and Information Science, 40(2), 71-80.

Chung, H. K., Ko, Y. M., Shim, W. \& Pyo, S. H. (2009). An Exploratory Meta Analysis of Library Economic Valuation Studies. Journal of the Korean Society for Library and Information Science, 43(4), 2009, 117-137. 
De Borger, B. \& Kerstens, K. (2000). What is known about municipal efficiency? The Belgian case and beyond. In: Blank, J. (Ed.), Public Provision and Performance: Contributions from Efficiency and Productivity Measurement. Elsevier, Amsterdam, 299-330.

Dunn, W. N. (2004). Public Policy Analysis: An Introduction. Pearson Prentice Hall, New Jersey.

Falkinger, J., Fehr, E., Gächter, S. \& Winter-Ebmer, R. (2000). A simple mechanism for the efficient provision of public goods: Experimental evidence. American Economic Review, 90(1), 247-264.

Ferguson, C. D. \& Bunge, C. A. (1997). The shape of services to come: Values-based reference service for the largely digital library. College \& Research Libraries, 58(3), 252-265.

Frantz, R. (1992). X-Inefficiency and allocative efficiency: what have we learned? American Economic Review, $82(2), 434-438$.

Gatenby, J. (2008). The Networked Library Service Layer: Sharing Data for More Effective Management and Cooperation. Ariadne, (56)4.

Hajek, P. \& Stejskal, J. (2014). Modelling Public Library Value using the Contingent Valuation Method: The Case of the Municipal Library of Prague. Journal of Librarianship \& Information Science, 47(1), 43-55.

Hájek, P., \& Stejskal, J. (2014). Library User Behavior Analysis-Use in Economics and Management. WSEAS Transactions on Business and Economics, 11(1), 107-116.

Hajek, P., Stejskal, J. \& Rehak, T. (2013). Bibliominig Users and their Willingness to Pay - Empirical Evidence from Municipal Library of Prague. In P. Jedlicka (Ed.), Proceedings from the Int. Conf. Hradec Economic Days 2013, Hradec Kralove, 95-100.

Hammond, C. J. (2002). Efficiency in the provision of public services: a data envelopment analysis of UK public library systems. Applied Economics, 34(5), 649-657.

Hemmeter, J. A. (2006). Estimating public library efficiency using stochastic frontiers. Public Finance Review, 34(3), 328-348.

Hider, P. (2008). Using the Contingent Valuation Method for Dollar Valuations of Library Services. The Library, 78(4), 437-458.

Holt, G. E., \& Elliott, D. (2003). Measuring outcomes: Applying cost-benefit analysis to middle-sized and smaller public libraries. Library Trends, 51(3), 424-440.

Holt, G., Elliott, D., Watts, A., \& Holt, L. E. (2000). Libraries are valuable . . Prove it! St. Louis: St. Louis Public Library.

Jantz, R. C. (2001). E-Books and New Library Service Models: An Analysis of the Impact of EBook Technology on Academic Libraries. Information Technology and Libraries, (20)2, 104-13.

Kim, G. (2011). A Critical Review of Valuation Studies to Identify Frameworks in Library Services. Library \& Information Science Research, 33(2), 112-119.

Kingma, B., \& McClure, K. (2015). Lib-value: Values, outcomes, and return on investment of academic libraries, phase III: ROI of the Syracuse University Library. College \& Research Libraries, 76(1), 63-80. 
Ko, Y. M., Shim, W. \& Pyo, S. H. (2015). Factors affecting users' assessment of the economic value of university library services. Journal of Librarianship and Information Science, 0961000614566338.

Ko, Y. M., Shim, W., Pyo, S. H., Chang, J. S. \& Chung, H. K. (2012). An Economic Valuation Study of Public Libraries in Korea. Library \& Information Science Research, 34(2), 117-124.

Kuipers, B. S., Higgs, M., Kickert, W., Tummers, L., Grandia, J., \& Van der Voet, J. (2014). The management of change in public organizations: A literature review. Public Administration, 92(1), 1-20.

Lee, S. J., \& Chung, H. K. (2012). Analyzing altruistic motivations in public library valuation using contingent valuation method. Library \& Information Science Research, 34(1), 72-78.

Lee, S. L., Chung, H. K. \& Jung, E. J. (2010). Assessing the Warm Glow Effect in Contingent Valuations for Public Libraries. Journal of Librarianship and Information Science, 42(4), 236-244.

López, R. (2005). Under-investing in public goods: evidence, causes, and consequences for agricultural development, equity, and the environment. Agricultural Economics, 32(s1), 211-224.

Lynch, M. J. (1983). Measurement of Public Library Activity: The Search for Practical Methods. Wilson Library Bulletin, 57(5), 388-93.

Noonan, D. S. (2003). Contingent valuation and cultural resources: a meta-analytic review of the literature. Journal of Cultural Economics, 27(3-4), 159-176.

Oakleaf, M. (2010). Value of Academic Libraries: A Comprehensive Research Review and Report. American Library Association: Chicago, IL.

Rooney-Browne, Ch. (2011). Methods for Demonstrating the Value of Public Libraries in the UK: A Literature Review. Library and Information Research, 35(109), 3-39.

Simpson, H. (2009). Productivity in public services. Journal of Economic Surveys, 23(2), 250-276.

Stejskal, J., \& Hajek, P. (2015). Effectiveness of digital library services as a basis for decision-making in public organizations. Library \& Information Science Research, 37(4), 346-352.

Stejskal, J., \& Hájek, P. (2015). Evaluating the economic value of a public service-the case of the Municipal Library of Prague. Public Money \& Management, 35(2), 145-152.

Stolarick, K. \& Silk, K. (2013). So Much More: The Economic Impact of the Toronto Public Library on the City of Toronto. Toronto: Martin Prosperity Insitute.

Van House, N. A. (1989). Output measures in libraries. Library Trends, 38(2), 368-279.

Van House, N., Lynch, M. J., McClure, C. R., Zweizig, D. L., \& Rodger, E. J. (1987). Output measures for Public libraries: A manual of standardized procedures. 2nd edition. Chicago: American Library Association.

Vitaliano, D. F. (1998). Assessing public library efficiency using data envelopment analysis. Annals of Public and Cooperative Economics, 69(1), 107-122.

Walter, V. A. (2003). Public library service to children and teens: A research agenda. Library Trends, 51(4), $571-$ 589. 
Worthington, A. (1999). Performance indicators and efficiency measurement in public libraries. Australian Economic Review, 32(1), 31-42. 